\title{
Atypical teratoid/rhabdoid tumor of the brain - A case with three secondary implants
}

\author{
Pedro Radalle Biasi', Paulo Sérgio Crusius², Cláudio Albano Seibert², \\ Marcelo Ughini Crusius ${ }^{3}$, Charles André Carazzo ${ }^{3}$, Cassiano Ughini Crusius ${ }^{3}$, \\ Cassiano Mateus Forcelinit, Adroaldo Baseggio Mallmann²
}

Faculdade de Medicina da Universidade de Passo Fundo, RS, Brasil; Instituto de Neurologia e Neurocirurgia, Passo Fundo, RS, Brasil.

\section{ABSTRACT}

Atypical teratoid/rhabdoid (AT/RT) of the brain is a rare malignant pediatric neoplasm that usually affects children around age two. This report is about a male patient, six months of age, who presented with seizures and decreased level of consciousness, progressing to numbness, oculomotor nerve palsy and tetra-spasticity. CT scan showed left cerebellopontine angle tumor. Magnetic resonance imaging (MRI) showed a solid lesion, hypointense on T1W and heterogeneous hyperintense on T2W, enhanced after contrast infusion, accompanied by three solid lesions, rounded and irregular in the left cerebellar hemisphere, occipito-parietal transition and right occipital lobe with no evidence of leptomeningeal spread, forming secondary implants. We conducted a biopsy, which confirmed ATI RT. Chemotherapic treatment was ineffective and the patient passed away quickly. In the literature review we found about 300 cases reported, as it is, therefore, extremely rare tumor with a mean age at diagnosis of 29 months. It can affect any area of the central nervous system, mainly infratentorial, being its main differential diagnosis medulloblastomas. The findings of secondary implantation without leptomeningeal spread seen in this patient are described in only one other case in literature. The clinical features usually are neurological deficits, seizures and coma. Its genesis stems from mutations in the gene hSNF5/INI1 on chromosome 22. Neuroimaging studies don't reveal radiological pattern suggesting AT/RT and the diagnosis is possible only through a biopsy with immunohistochemical analysis. The available treatments are ineffective, and death is the outcome, with $84 \%$ in six months.

\section{KEYWORDS}

Rhabdoid tumor, brain neoplasms.

\section{RESUMO}

Tumor rabdoide/teratoide atípico de encéfalo - um caso com três implantes secundários O tumor rabdoide/teratoide atípico (AT/RT) do encéfalo é uma neoplasia pediátrica maligna rara que acomete geralmente crianças ao redor dos dois anos. O caso descrito é de um paciente masculino, de seis meses de idade, que apresentou convulsões e diminuição do nível de consciência, evoluindo com torpor, paralisia do nervo oculomotor e tetraespasticidade. Exame de tomografia evidenciou neoplasia do ângulo ponto-cerebelar esquerdo. A ressonância magnética (RNM) demonstrou lesão sólida, hipointensa em T1, e heterogênea e hiperintensa em T2, realçada após contraste, acompanhada de três lesões sólidas, arredondadas e irregulares no hemisfério cerebelar esquerdo, transição occipito-parietal direita e lobo occipital direito, sem sinais de disseminação leptomeníngea, constituindo implantes secundários. Realizou-se então uma biópsia, que confirmou AT/RT. O tratamento realizado por meio de quimioterapia foi ineficaz e o óbito ocorreu rapidamente. Na revisão de literatura encontramos pouco mais de 300 casos descritos, tratando-se, portanto, de neoplasia extremamente rara, com média de idade ao diagnóstico de 29 meses. Pode acometer qualquer área do sistema nervoso central, com predomínio infratentorial, sendo seu principal diagnóstico diferencial os meduloblastomas. Os achados de implantação secundária sem disseminação leptomeníngea encontrados neste paciente são descritos em apenas um outro caso na literatura. O quadro clínico costuma cursar com déficits neurológicos, convulsões e coma. Sua gênese decorre de mutações no gene hSNF5/INI1 do cromossomo 22. As neuroimagens não revelam padrão específico, sendo o diagnóstico possível somente mediante biópsia com análise imuno-histoquímica. Os tratamentos disponíveis são ineficazes, e o óbito constitui a via final, ocorrendo $84 \%$ destes nos primeiros seis meses.

\section{PALAVRAS-CHAVE}

Tumor rabdoide, neoplasias encefálicas.

1. Acadêmico do $5^{\circ}$ ano de Medicina da Universidade de Passo Fundo - RS, Brasil.

2. Neurocirurgião do Instituto de Neurologia e Neurocirurgia de Passo Fundo, professor da disciplina de Neurologia da Faculdade de Medicina da Universidade de Passo Fundo - RS, Brasil.

3. Neurocirurgião do Instituto de Neurologia e Neurocirurgia de Passo Fundo - RS, Brasil.

4. Neurologista do Instituto de Neurologia e Neurocirurgia de Passo Fundo, professor da disciplina de Farmacologia da Faculdade de Medicina da Universidade de Passo Fundo - RS, Brasil. 


\section{Introduction}

Central nervous system (CNS) atypical teratoid/rhabdoid tumor (AT/RT), also known as malignant rhabdoid tumor, is a rare and aggressive pediatric neoplasm. . $15,20^{2}$ Initially described in 1978 as a rhabdomyosarcomatous variant of Wilms' tumor, it came to be accepted as a distinct entity of CNS only in the mid-80 after Rorke et al. ${ }^{16-18}$ studies. Even though the brain is the most common extrarenal place, there are reports of localization in thymus, liver and sites of soft tissue..$^{23}$ The databases for research have about 300 cases reported so far.

Having an extremely malignant feature, it has a typically intra-axial location with predilection for the posterior fossa (two thirds of cases). ${ }^{15}$ It usually occurs in children who are around two years old, and it can lead to an easy and common misdiagnosis of medulloblastoma, which shows similar radiological features. ${ }^{7,15,20} \mathrm{Up}$ to now this is the first and only CNS pediatric tumor with gene identification responsible for tumor suppression. A mutation or deletion in the germline gene hSNF5/ INI1 in chromosome $22 \mathrm{q} 11$ is found in $75 \%$ of the cases. ${ }^{3,7,9,10,20,23}$ All kinds of treatment - Radiotherapy, Chemotherapy and Surgery - have been ineffective with poor prognosis. ${ }^{7,911,20}$

It's described the case of a six-year-old patient with AT/RT diagnosis in topography of the brainstem, with secondary implantation and a review of the characteristics of previously reported cases.

\section{Case report}

A six-year-old male patient, admitted for bronchiolitis and pneumonia, started having seizures with decreased consciousness level. In the neurological assessment it was found decreased consciousness level (GCS 09), oculomotor nerve palsy and tetra-spasticity. Then computed tomography (CT) of brain was performed, which showed slightly hyperdense brain neoplasm presenting intense homogeneous enhancement after contrast infusion going from left cerebellopontine angle to left cerebral ventricle and trigon of the right lateral ventricle through tentorium of the cerebellum, with slightly dilatation of the lateral and third ventricles. The magnetic resonance image (MRI) revealed solid expansive lesion with hypointense signal in T1W sequence and heterogeneously hyperintense in $\mathrm{T} 2 \mathrm{~W}$ sequence, with intense enhancement and heterogeneous by contrast means (Figure 1), suggestive intra-tumor necrosis, having surrounding edema determining mass effect over the IV ventricle. It was seen other three solid lesions, they were rounded and had irregular outline, hypointense in
T1W and hyperintense in T2W and FLAIR, with intense enhancement and homogeneous by contrast means, located in the right cerebellar hemisphere (Figure 2), in the transition between occipital lobes and parietal on the right (Figure 3), and in the right occipital lobe (Figure 4). There weren't evidences of leptomeningeal spread.

It was done a stereotactic biopsy. Histopathology pointed out round neoplastic cells of eosinophilic cytoplasm sometimes of lacy aspect with voluminous, oval or rounded nuclei situated peripherally with chromatin and prominent nucleoli; necrotic areas and sites of atypical mitosis were found as well. Through immunohistochemistry these cells showed positivity for cytokeratin markers, EMA (epithelial membrane antigen), vimentin, Ki-67 and actin, thereby constituting atypical teratoid/rhabdoid tumor.

Four days after the biopsy, the patient showed respiratory dysfunction and was placed to mechanical ventilation. At the same time the first cycle of chemotherapy was started by HEAD START II protocol, which includes cisplatin, cyclophosphamide, etoposide, filgrastim and vincristine. At about twenty days later, another CT was done to check the development of the case.

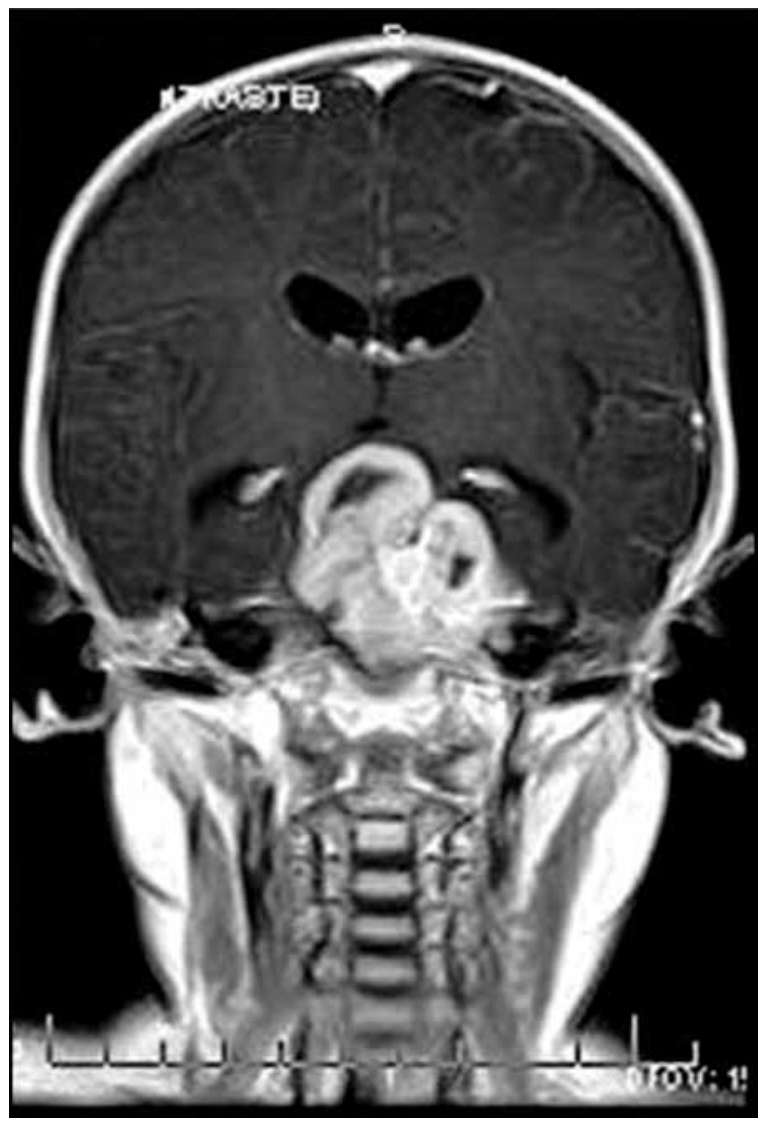

Figure 1 - Coronal MR image on T1W contrasted shows the brainstem AT/RT with heterogeneous contrast enhancement with areas of non-enhanced tumor. The lesion produces mass effect to the left temporal lobe. 


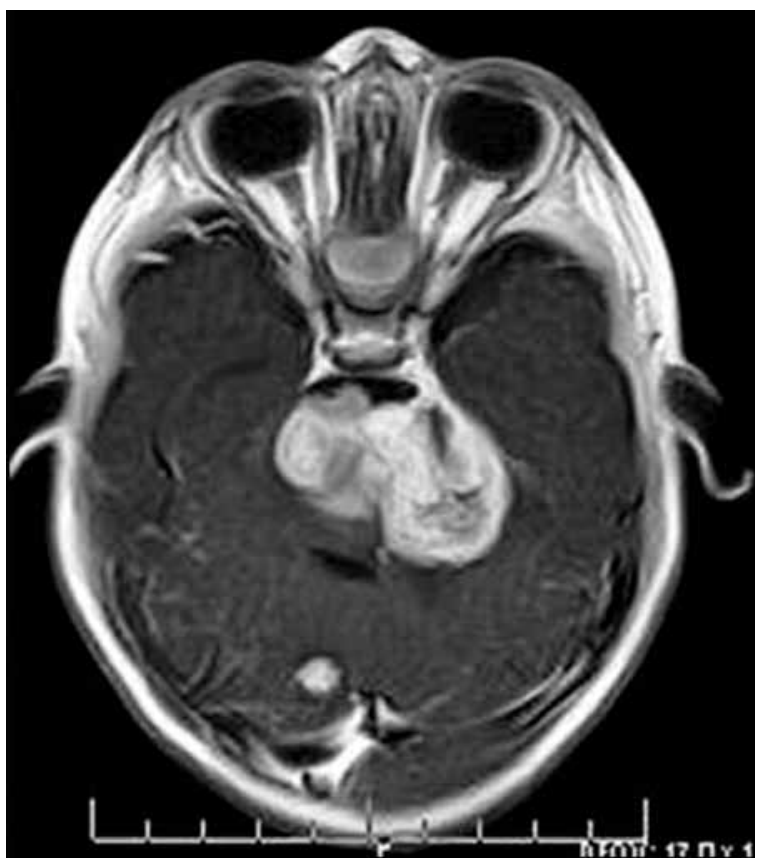

Figure 2 - Axial MR image on T1W sequence with contrast shows the AT/RT with posterior spread and mass effect to the left temporal lobe. Note the presence of a rounded, high enhanced lesion on the right cerebellar hemisphere, without signs of leptomeningeal spread, constituting secondary implants.

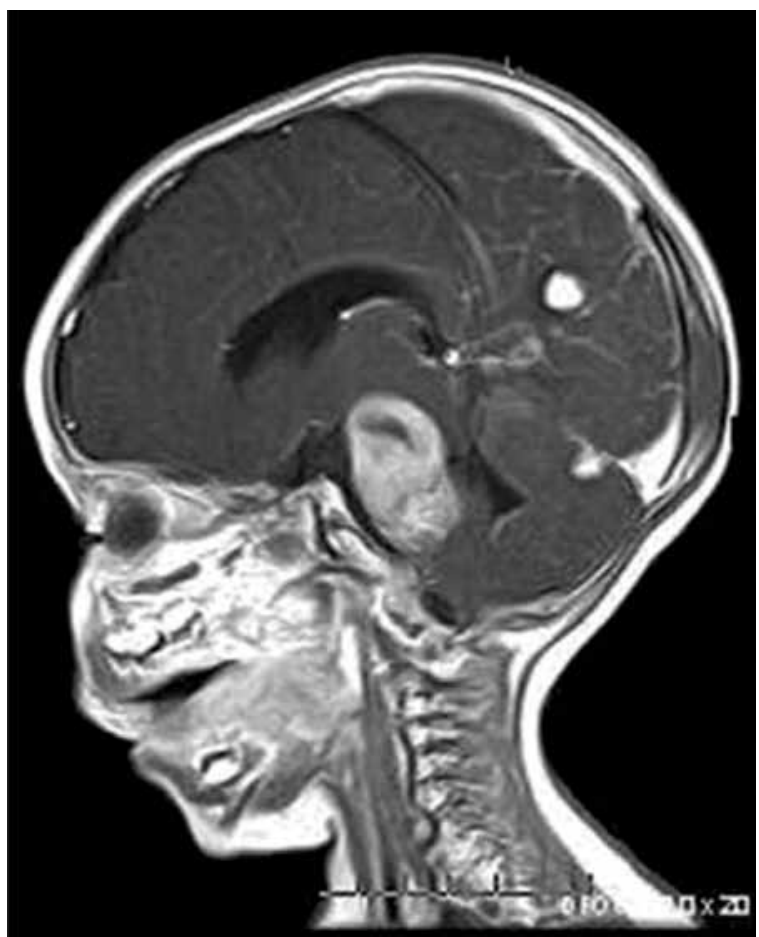

Figure 3 - Sagittal MR image on T1W sequence with contrast shows the AT/RT of the brainstem, the secondary implant on the right cerebellar hemisphere and another rounded, high-enhanced lesion located on the transition between right occipital and parietal lobes, constituting other secondary implant.

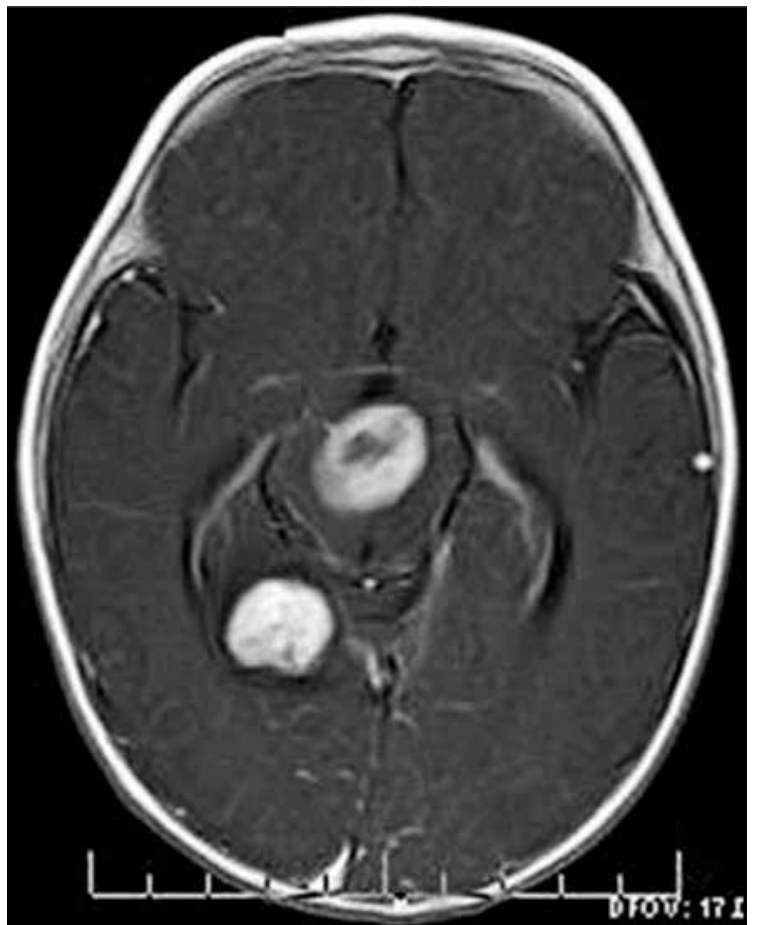

Figure 4-Axial MR image on T1W sequence with contrast shows the AT/RT of the brainstem and other rounded, high-enhance lesion on the right occipital lobe, constituting another secondary implant.

This CT, though, revealed persistence of neoplasia with no sign of answer to the chemotherapy. Afterwards, the patient developed neutropenia and, consequently, pneumonia, which leaded the interruption of chemotherapy. When the pneumonia was controlled, the patient came back to the treatment and the second cycle of chemotherapy started.

Two months after the admission, CT of control showed expansion of neoplastic lesion and significant obstructive hydrocephalus. The patient passed away because of complications of the neoplasia 77 days later the initial presentation.

\section{Discussion}

The atypical teratoid/rhabdoid tumor is a pediatric neoplasm extremely aggressive and uncommon., ${ }^{9,15,20}$ WHO defines it as a CNS malignant embryonal tumor composed of rhabdoid cells with cell fields like primitive neuroectodermal tumor (PNET), epithelial tissue and neoplastic mesenchyme. WHO also defines it as grade IV. ${ }^{9}$ It has as main differencial diagnoses teratomas, chroid plexus papilloma, ependymoma and mainly PNET/Medulloblastomas. ${ }^{9,15,20}$ 
AT/RT incidence isn't known, it affects in most cases from newborns to teenagers, mainly children under two years old. ${ }^{7,15,20}$ Rahmat et al. ${ }^{15}$ reports the average age to diagnosis is 29 months. There are only 18 reports in adults. ${ }^{24}$

AT/RT tumor may occur in any area of CNS, it was described by Meyers et al. ${ }^{12}$ in a series of 17 cases, a predominance of infratentorial region, affecting $47 \%$ of the cases, others $41 \%$ happen in the supratentorial region, mainly in the left hemisphere, and $12 \%$ (two cases) in both regions of the brain, constituting invasion by contiguity. The involvement of the spinal cord is described in few reports. ${ }^{1,4,5,8,13,14,19,21,22,24}$ Findings of secondary implantation without evidence of leptomeningeal spread are an extremely unusual way of presentation of this pathology, being this the second case found with secondary implantation. ${ }^{6}$

The tendency to leptomeningeal infiltration by this tumor makes it clear its malignancy with CSF dissemination in half of patients and subarachnoid invasion in a third. ${ }^{9,15,20,23}$

The clinical features usually are focal neurological abnormalities, seizures and sudden decrease of consciousness level caused by hydrocephalus and/or mass effects caused by the lesion. In cases of supratentorial lesions, there are more neurological deficits and slower decay. ${ }^{3,9,23}$

Although many studies suggest the possibility of diagnosis AT/RT through imaging studies, only the immunohistochemical findings and light microscopy are capable of making the diagnosis. ${ }^{3,12,15}$ At pathologic analysis, it can be checked two types of tumor presentation, one with rhabdoid cells exclusively, rarer, and other with a mixture of cells similar to PNET, whose components are generally larger and more pleomorphic than those typically found in medulloblastomas, and it responds for $70 \%$ of cases. The rhabdoid cell, main element of this tumor and responsible for its distinctive features, is a cell with hyaline cytoplasmic inclusions and abundant eosinophils, of large vesicular nuclei and prominent nucleoli, positive for immunohistochemical markers vimentin, EMA and smooth muscle actin. . 2,3,9,15 $^{2}$

The histology of this rare tumor is described as a result of genetic mutations in $75 \%$ of the cases. Genetic studies showed an alteration due to monosomy or deletions on chromosome 22q11 affecting germline gene hSNF5/INI1. ${ }^{3,7,9,20,23}$ Allen et al. ${ }^{2}$ showed a mutation in exon 9 of the INI1 gene that was the responsible for the progression of an optic pathway ganglioglioma for an AT/RT.

Neuroimaging studies don't reveal radiological pattern suggesting AT/RT. Computed tomography and MRI are variable due to intratumoral changes that may occur, and they don't provide enough information to differ from other neoplasms. On non-contrasted CT, images are typically isodense or slightly hyperdense, with edema, calcifications, cysts, intratumoral hemorrhage and necrosis. After contrast administration, the image becomes heterogeneous, and this is because of the tumor histologic complexity. These findings are also common in Ependymomas and PNET's. In the MR images, the lesions show mixed signal both reflected on T1W and T2W, due to intratumoral hemorrhage occurrence with extensive necrosis. At T1W, the solid component of the lesion appears as hypointense image or isointense image, and T2W as hyperintense image or isointense. . $3,12,15,20,23^{2}$

In the posterior fossa, the AT/RT has tendency to occur off-midline, unlikely from what happens with ependymomas and PNET's. ${ }^{3,9,10}$ In the cases located supratentorially, the neuroimaging is similar to other tumors. $^{3}$

Current treatment techniques consist of multimodal approaches, including multiple surgeries, use of various chemotherapeutic agents and radiotherapy, but these are still ineffective for curing the disease. Complete tumor excision surgery is difficult and when it's performed, it doesn't prevent the recurrence of the same. ${ }^{9,11,20} \mathrm{~A}$ study of the Children's Hospital of Cleveland in the United States suggests an approach in second moment for excision of residual tumors, thus reaching an increase in survival from 9.25 to 14 months. ${ }^{3}$ In persistence of a tumor, adjuvant therapies are joined, which includes chemotherapy with multiple agents and radiotherapy in selected cases. ${ }^{9}$ The tumor is sensitive to chemotherapy ${ }^{3}$, but it is not always evident in practice, as in our case, where after two sessions of HEAD START II protocol, the neoplasia continued developing leading the patient to death in a time range of three months. The intrathecal chemotherapy has shown better results and also it is of great importance in cases that the patient persisted with residual tumor after surgery but can't receive radiotherapy, fact typically seen in children younger than three years old. ${ }^{3}$

The use of radiotherapy shows an improvement in survival, and Hilden et al. ${ }^{7}$ reached 48 months, much more than the 17 months reported with major frequency for this tumor. All this, however, is achieved despite a significant cognitive impairment. ${ }^{3,9}$

The stem-cell rescue (SCR) therapy has been a plausible and an effective alternative, but it is still object of many studies to demonstrate its applicability. The therapeutic protocol with high doses of chemotherapy and SCR for treatment of pediatric brain tumors of high risk is the objective of study in American pediatric clinical trials currently under development. Their results are expected with anxiety, hoping that they reveal better results than those known nowadays. ${ }^{3}$ 
The evolution of this tumor is very variable, but the death is premature. ${ }^{3,9,20}$ Eighty-four percent occur in the first six months, even with aggressive therapy, and in cases of subarachnoid invasion or infratentorial primary site occurs in 2.5 months. ${ }^{15}$

It is clear the attention that must be given to this peculiar neoplasm, of not estimated incidence due to its rarity, with difficult suspicion faced to nonspecific neuroimaging, but it fits the differential diagnosis of tumors such as medulloblastomas, particularly common in pediatric patients. The poor prognosis will persist while it is not found effective increments to the current treatment techniques.

\section{References}

1. Agrawal A, Bhake A, Cincu R. Giant lumbar paraspinal atypical teratoid/rhabdoid tumor in a child. J Cancer Res Ther. 2009;5(4):318-20.

2. Allen JC, Judkins AR, Rosenblum MK, Biegel JA. Atypical teratoid/rhabdoid tumor evolving from an optic pathway ganglioglioma: case study. Neuro Oncol. 2006;8(1):79-82.

3. Arslanoglu A, Aygun N, Tekhtani D, Aronson L, Cohen $\mathrm{K}$, Burger $\mathrm{PC}$, et al. Imaging findings of CNS atypical teratoid/rhabdoid tumors. AJNR Am J Neuroradiol. 2004;25(3):476-80.

4. Bannykh S, Duncan C, Ogle E, Baehring JM. Atypical teratoid/rhabdoid tumor of the spinal canal. J Neurooncol. 2006;76(2):129-30.

5. Fridley JS, Chamoun RB, Whitehead WE, Curry DJ, Luerssen TG, Adesina A, et al. Malignant rhabdoid tumor of the spine in an infant: case report and review of the literature. Pediatr Neurosurg. 2009;45(3):237-43.

6. Gandhi CD, Krieger MD, McComb JG. Atypical teratoid/ rhabdoid tumor: an unusual presentation. Neuroradiology. 2004;46(10):834-7.

7. Hilden JM, Meerbaum S, Burger P, Finlay J, Janss A, Scheithauer BW, et al. Central nervous system atypical teratoid/rhabdoid tumor: results of therapy in children enrolled in a registry. J Clin Oncol. 2004;22(14):2877-84.

8. Kodama H, Maeda M, Imai H, Matsubara T, Taki W, Takeda K. MRI of primary spinal atypical teratoid/rhabdoid tumor: a case report and literature review. J Neurooncol. 2007;84(2):213-6.

9. Kumar R, Giri P, Kumari N, Kalra S. Primary malignant rhabdoid tumors of the central nervous system: clinicoradiological study of three cases and their outcome. J Pediatr Neurol. 2007;5:61-6.

10. Lee YK, Choi CG, Lee JH. Atypical teratoid/rhabdoid tumor of the cerebellum: report of two infantile cases. AJNR Am J Neuroradiol. 2004;25(3):481-3.
11. Marachelian A, Butturini A, Finlay J. Myeloablative chemotherapy with autologous hematopoietic progenitor cell rescue for childhood central nervous system tumors. Bone Marrow Transplant. 2008;41(2):167-72.

12. Meyers SP, Khademian ZP, Biegel JA, Chuang SH, Korones DN, Zimmerman RA. Primary intracranial atypical teratoid/rhabdoid tumors of infancy and childhood: MRI features and patient outcomes. AJNR Am J Neuroradiol. 2006;27(5):962-71.

13. Moeller KK, Coventry S, Jernigan S, Moriarty TM. Atypical teratoid/rhabdoid tumor of the spine. AJNR Am J Neuroradiol. 2007;28(3):593-5.

14. Niwa T, Aida N, Tanaka M, Okubo J, Sasano M, Shishikura A, et. al. Diffusion-weighted imaging of an atypical teratoid/ rhabdoid tumor of the cervical spine. Magn Reson Med Sci. 2009;8(3):135-8.

15. Rahmat K, Kua CH, Ramli N. A child with atypical teratoid/ rhabdoid tumour of the posterior cranial fossa. Singapore Med J. 2008;49(12):365-8.

16. Rorke LB, Biegel JA. Atypical teratoid/rhabdoid tumor. In: Kleihues P, Cavenee WK, editors, World Helath Organization Classification of Tumorsin Pathology \& Genetics. Tumors of The Central Nervous System. Lyon: IARC Press; 2000. p. 145-8.

17. Rorke LB, Gilles FH, Davis RL, Becker LE. Revision of the World Health Organization classification of brain tumors for childhood brain tumors. Cancer. 1985;56(7 Suppl):1869-86.

18. Rorke LB, Packer RJ, Biegel JA. Central nervous system atypical teratoid/rhabdoid tumors of infancy and childhood: definition of an entity. J Neurosurg. 1996;85(1):56-65.

19. Tanizaki Y, Oka H, Utsuki S, Shimizu S, Suzuki S, Fujii K. Atypical teratoid/rhabdoid tumor arising from the spinal cord--case report and review of the literature. Clin Neuropathol. 2006;25(2):81-5.

20. Tez S, Köktener A, Güler G, Ozisik P. Atypical teratoid/ rhabdoid tumors: imaging findings of two cases and review of the literature. Turk Neurosurg. 2008;18(1):30-4.

21. Yang CS, Jan YJ, Wang J, Shen CC, Chen CC, Chen M. Spinal atypical teratoid/rhabdoid tumor in a 7-year-old boy. Neuropathology. 2007;27(2):139-44.

22. Yano S, Hida K, Kobayashi H, Iwasaki Y. Successful multimodal therapies for a primary atypical teratoid/ rhabdoid tumor in the cervical spine. Pediatr Neurosurg. 2008;44(5):406-13.

23. Yoon CS, Chuang S, Jay V. Primary malignant rhabdoid tumor of the brain: CT and MR findings. Yonsei Med J. 2000;41(1):8-16.

24. Zarovnaya EL, Pallatroni HF, Hug EB, Ball PA, Cromwell LD, Pipas JM, et al. Atypical teratoid/rhabdoid tumor of the spine in an adult: case report and review of the literature. J Neurooncol. 2007;84(1):49-55.

\section{Endereço para correspondência}

Pedro Radalle Biasi

Av. Sete de Setembro, 176 A, ap. 202

99010-120 - Passo Fundo, RS, Brasil

pr.biasi@brturbo.com.br 